\title{
Particular issues of legal regulation of non-contractual liability in maritime transport
}

\author{
Andrey Viktorovich Semenov* \\ Civil and International Law Department, Admiral Ushakov Maritime State University, Novorossiysk, Russia
}

\begin{abstract}
A distinctive feature of non-contractual liability as a legal concept is the existence of noncontractual liability for parties that are not in a contractual relationship with each other. The damage caused in this case will be recognized as a consequence of actions not related to the violation of contractual obligations. In this situation, the tortfeasor violates the general absolute obligation not to encroach on other people's subjective rights. It should be noted that non-contractual liability is often equated with delictual liability arising from harm. Delictual liability is the most common among non-contractual liability. However, the concept of non-contractual liability is much deeper and subject to expanded interpretation, that is, it includes various cases of liability in the absence of contracts besides delictual liability. Problematic issues related to non-contractual liability in maritime transport are an urgent problem in contemporary legislation. Resolving the given issues will be useful for law enforcement. The author investigates problematic issues of the application of non-contractual liability in maritime transport, and proposes to clarify and supplement the legislation in the field under consideration.
\end{abstract}

\section{Introduction}

The development of maritime activities inevitably leads to an increase in the number of accidents including heart attacks; and this trend is constantly growing as a result of the most unexpected factors when working on sea vessels. Accordingly, the number of cases of causing harm is enhancing, the resolution of which in civilized countries is simplified, and in others it becomes more complicated.

Death on a maritime vessel or the receipt of injury and disability are obligations of harm and represent one of the most significant institutions of international maritime private law and civil legislation in Western countries. The obligations are aimed at making amends to the sailor regardless of the contractual relationship or lack thereof.

Legislative systems in most countries are based on the general concept of "delict" as a wrongful act and the element for a comprehensive "general delict", namely, strict liability. If known conditions of delictual liability are necessary in its usual concept, then their absence in the "strict" liability is not a reason for releasing the vessel owner from liability, including his fault absence, which allows us to speak of "strict" liability. It is a kind of exception to the general rule. Establishment of negligence elements in the defendant actions is enough.

Almost all countries have new legislation and are improving the old ones. There is a tendency to expand the scope of obligations from causing harm, including the formation of the strict liability institute of the vessel owner (employer). It is also a non-contractual liability, since the obligation to compensate for innocent harm to the health of the crew is not considered even when concluding a lease agreement with the crew. For instance, a heart attack does not belong to the culpable infliction of harm to health, however, such liability is insured, which means that it is present by default.

We compare domestic and foreign practice, legislation of Russia and other countries in order to see into a matter [1].

\section{Problem statement}

Since delictual liability as a type of non-contractual liability is most common in life, its delimitation from contractual liability is of greatest interest. The most significant differences in the content of contractual and delictual liabilities are highlighted in the juridical literature.

With respect to the practical application of contractual and delictual obligations, this question arises quite often and concerns, primarily, the delimitation of the scope of contractual and delictual obligations, and, as a consequence, the application of either delictual or contractual liability. In our opinion, in most cases such a legal position is explained by the factor that the legal norms acting as a regulator of one or another type of liability significantly differ in a number of cases.

Note that the application of non-contractual liability is established by law, if we are engaged in the definition of such elements as shape and size that characterize it. Moreover, the disposition prerogative is absent from the legislator in this version, these are mandatory norms. In

\footnotetext{
Corresponding author: novolawyer@inbox.ru
} 
the case when the question about the contractual form of liability arises, the given issues are resolved using a combination of two factors - both the law and the agreement of the parties (contract). If one and the same case is considered according to the norms of contractual liability, then one result may be obtained, and if according to the norms of delictual liability, then another one.

\begin{tabular}{|c|}
\hline $\begin{array}{c}\text { Significant differences in the content of contractual and } \\
\text { delictual liability }\end{array}$ \\
\hline $\begin{array}{c}\text { Fules on delictual liability are established in peremptory } \\
\text { norms that exclude the discretion of the parties when } \\
\text { determining the conditions and amount of liability. }\end{array}$ \\
In contractual relations, the norms on liability are, \\
generally, dispositive. \\
Parties have the right to change or establish other liability \\
not provided for by law. \\
Second \\
Delictual liability is stricter than contractual one, since it \\
arises even in the absence of the victim's fault \\
Third \\
\hline $\begin{array}{c}\text { Principle of full compensation for harm is carried out } \\
\text { consistently in delictual liability. }\end{array}$ \\
\hline pontractual liability of defaulting debtors is, generally, a \\
participatory share obligation.
\end{tabular}

Fig. 1. Differences in the content of contractual and delictual liability

The task of delineating the types of responsibility that arises in such cases is solved as follows. If harm (loss) occurs as a result of non-fulfillment or improper fulfillment of a contractual obligation, then the norms on liability for delict are not applied, and the harm is compensated in accordance with the rules on liability for non-fulfillment of a contractual obligation or in accordance with the terms of an agreement concluded between the parties.
Clause 2 of Art. 204 RF MSC - charterer's liability for damage caused to the vessel is established in an indirect form, when such damage goes beyond normal wear and tear

Art. 207 RF MSC - charterer is not liable for losses caused by the salvage, loss or damage of the chartered vessel, unless it is proven that the losses have been caused through the charterer fault

Art. 220 RF MSC - losses caused by salvage, loss or damage of the vessel shall be borne by the charterer, unless he proves that the losses have been caused through no fault of his

Art. 207 RF MSC - presence of the charterer fault is not assumed, it must be proven in every specific case as a condition of liability ?

Art. 220 RF MSC - charterer is guilty unless the contrary is proved;

$\rightarrow$ depending on whether the parties have concluded a time charter or bareboat charter, obligation to prove the absence of fault may be imposed $\rightarrow$ on both the vessel owner and the charterer;

absence of fault (intent or negligence) of the charterer may be caused by the fact that the losses occurred through the fault of the vessel owner, for example, in consequence of his failure to bring the vessel into a seaworthy state by the time it is handed over to the charterer;

$\sqrt{ }$ salvage, damage or loss of the chartered vessel may also be caused by the actions of third parties or any other accidental circumstances stipulating such a situation in which the charterer could not and should not have prevented the infliction of losses;

$\sqrt{ }$ charterer is also exempt from liability in the event of damage owing to insuperable force.

Fig. 2. Features of the non-contractual liability under a maritime vessel lease agreement.

\section{Materials and methods}

We compare domestic and foreign practice, legislation of Russia and other countries in order to see into a matter.

In the United States, issues of non-contractual liability are resolved by referring to the Merchant Marine Act of 1920, known as the Jones Act not only in legal circles but other spheres [2]. If we literally follow the terminology of the Act, maritime accidents occurring with people who, on the basis of working documents, are members of the vessel's crew, are considered "sea hazards."

The Jones Act was a vehicle for the implementation of judicial protection against negligence of the vessel owner (vessel operator) for sailors. According to the interpretation of the document, any sailor, regardless of the rank and experience of sailing on vessels in general and this vessel in particular, who suffers from injury on the vessel, has the opportunity, guided solely by his choice, to take action to cover damage under the law. Pursuant to the Jones Act, it is the duty of proof for the 
sailor (plaintiff) to establish that his employer or agent has been negligent, which, owing to elementary principles of causality, is the cause of the accident. Negligence, even the smallest, is sufficient to sue.

This is a very interesting document from the point of view of the relationship between the norms of law, morality and the equality of everybody in the eyes of the law. However, it follows from everything we have cited that this equality goes to the side of a simple sailor, whose duties include the conscientious fulfillment of his obligations, but not a thorough study of the law rules. Thus, it is possible to identify the main principle that the Court rules by default. It is the employer's responsibility to provide the sailor with a safe place to work. In this case, the task of the jury is simple, but at the same time scrupulous - to check the presence of even minor negligence on the part of the employer.

The Jones Act is generally practiced in favor of the sailor, and the employer (vessel owner) or his agent bears strict liability if the vessel conditions do not meet safety requirements. Thus, the Jones Act provides the plaintiff's representative with essential "tools" to seek justice on behalf of injured or perished sailors to their families.

In Russia, obligations from causing harm in marine transport are covered by the concept of "delictual obligations" and are resolved by the Civil Code of the Russian Federation (Ch. 59). Unfortunately, RF MSC practically does not resolve this category of cases, referring them to the Civil Code of the Russian Federation, although it contains grounds that allow it to be applied to obligations from causing harm on maritime vessels in terms of their arrest under one of the types of maritime requirements arising from "causing harm to the life or health of a citizen on land or on water in direct connection with the vessel operation" [3].

Russian practice does not name and does not mean a heart attack at the workplace (vessel). A heart attack is investigated on equal bases, like an ordinary vessel event associated with an accident on a vessel. RF MSC does not solve the given problems, emphasizing its indifference and disregard to the fate of sailors. Apparently, this explains Russia's non-participation in ILO Convention No. 55 "On the obligations of the vessel owner in the event of illness, injury or death of sailors" of 1949 with amendments of 2006 [4].

This time Russia joined the Convention in January 2006, 11 years later, in 2017.

ILO Convention No. 134 (Art. 1) on occupational accidents means all accidents occurring to a sailor during or related to work. Article 2 obliges the competent authorities in each country to take measures in order to ensure that industrial accidents are properly investigated and reported. ILO Convention No. 142 on the prevention of occupational accidents among sailors provide for the following: special physiological and psychological problems caused by the environment on board and problems arising from physical stress on board, in particular from increased workload.

In Geneva, the Maritime Labor Convention of 2006 was adopted with the aim of creating a single agreed act, covering, as far as possible, all current norms of existing international conventions and recommendations on labor in maritime navigation, as well as the fundamental principles contained in other international labor conventions.

In the Russian Federation, this Convention was ratified in 2012. From that moment, work on bringing the normative legal regulation in compliance with the MLC 2006 standards began.

Currently, not all the requirements of the MLC 2006 are reflected in Russian legislation, which creates a number of issues requiring the development of appropriate solutions to ensure the complete realization of the labor and social rights of sailors.

The general principle of responsibility without fault is based on the concept of objectivity and is associated with the use of an increased danger source [5].

The establishment of objective liability for harm caused by an increased danger source led to the replacement of the guilt principle as a basis for delictual liability by the concept of "risk." In this regard, vessel owners are not responsible for "fault", but for the danger taking place on the vessel. Such strict liability for harm is covered by special legislation [6].

In foreign law, these cases are covered by the system of "general delict (quasi-delict)", since incidents at sea are, generally, imprudent in nature. An irrefutable presumption of guilt applies to the liability of the vessel owner (employer) for the caused damage: they are deprived of the opportunity to prove their innocence, especially in the event of the sailor death. Numerous special laws of a number of countries regulating liability for harm establish the strict liability of the defendant (delinquent).

Cause of death is not considered when insuring a sailor's life as it cannot be predicted. Nevertheless, the vessel owner, as it would seem, should be responsible for the death of a vessel crew member in the presence of guilt, which cannot be established in a number of cases. A causal link between the death of a vessel crew member and the vessel's administration has to be looked for [7]. Therefore, vessel owners insure the life of a crew member not for fault, but against the risk of possible death.

Liability for harm due to negligence is meant when considering the liability of the vessel owner for the occurrence of a heart attack in a vessel crew member on the vessel [8]. The main stages of the given liability are shown in the diagram.

\begin{tabular}{|l|}
\hline \multicolumn{1}{|c|}{ Main stages of the vessel owner liability for harm } \\
due to negligence
\end{tabular}

Fig. 3. Main stages of the vessel owner liability for harm due to negligence 


\section{Results and Discussion}

Within the framework of the issue, we consider the improvement of the existing legal regulation in the following directions.

On the implementation of Regulation 4.2 "Liability of vessel owners" Maritime Labor Convention of 2006. In connection with the entry into force in January 2017 of the amendments adopted in 2014, which provide for a system of financial guarantees ensuring the payment of compensation in the event of the sailor death or longterm disability due to occupational injury, illness or danger, it is necessary to clarify which competent authority will enforce compliance with these new requirements of MLC 2006. Nowadays, the requirements enforcement of regulation 4.2 of MLC 2006 is completely entrusted to the Russian Ministry of Transport.

At the same time, in accordance with paragraph 2 of Standard A 4.2.2, the form of the financial guarantee system, which can be established either in the form of a social security system, or insurance, or a national fund, or some other similar Scheme, must be determined by the state.

In the Russian Federation, the specified requirements of MLC 2006 are implemented through the practice of voluntary insurance of vessel owners' liability. Moreover, the system of the Federal Law of July 24, 1998 No. 125-FZ "On compulsory social insurance against accidents at work and occupational diseases" is in force, the requirements of which, in our opinion, are equivalent to the requirements of the conventional standard. However, the problem of issuing documents confirming the existence of this insurance type by the Social Insurance Fund of the Russian Federation, and meeting the requirements of MLC 2006, has not been solved.

As a result, Russian vessel owners are forced to insure their liability twice.

It can be assumed that the system of compulsory social insurance against industrial accidents and occupational diseases in relation to sailors should be brought in line with the requirements of Regulation 4.2, for which it is necessary to include the requirements established by MLC 2006 to the system in the current legislation (par. 8, 9 and 13 of Standard A 4.2.1 and par. 1 and 3 of Standard A 4.2.2) and the content of the written certification or other documentary evidence of financial guarantees and its storage order (par. 11 and 14 of Standard A 4.2.1).

It should be noted that RF MSC, the 1999 Convention on the Arrest of Vessels, allowing for the possibility of preliminary securing a claim for marine requirements in the form of the seizure of a seagoing vessel, presupposes the fault of the vessel owner [9]. Thus, it is necessary to supplement the liability of the vessel owner in RF MSC with a new type of strict liability for damage in connection with the death or injury of a vessel crew member as a specific type of maritime accident.

\section{Conclusion}

It is indispensable to envisage a provision limiting the non-contractual liability for requirements against the vessel owner in relation to compensation for harm caused to life or health of the sailor in order to address the issue of limiting non-contractual liability to RF MSC. At the same time, it is required to oblige the vessel owner to insure the risk of liability for the given obligations in an amount equal to the sum payable in case of non-contractual liability. Payment of compensation on the basis of limited non-contractual liability does not cause difficulties for Russian and foreign vessel owners, when such liability is insured in mutual insurance clubs [10].

The legal limitation of the vessel owner's liability is not a restriction or extension of rights of a seafarer or an employer, but is aimed at balancing their rights and obligations.

\section{References}

1. S.K. Abramyan, K.V. Golubkina, Interdepartmental interaction of water transport management bodies of the Russian Federation, Marine Intellectual Technologies, 1-2(43) (2019).

2. M.Z. Abesalashvili, Legal regulation of the parties under the vehicle rental agreement with the crew, Problems of economics and legal practice, 5 (2011)

3. M.I. Lavitskaia, Features of the definition and functions of civil liability, International Conference on Advances in Environment Research: Conference proceedings (Madrid, Spain, 2021).

4. Shipowners' Liability (Sick and Injured Seamen) Convention. Conventions and Recommendations adopted by the International Labour Conference. 1919 - 1956 (1991).

5. V.V. Zaslonov, A.A. Golovina, A.N. Popov, Creating a Crewless Ship in the Framework of the Technological Paradigm of the Russian Federation, Lecture Notes in Networks and Systems, 115 (2020).

6. A.V. Dobrovinskaia, Delictual liability of a carrier as a small and medium-sized business entity, Civil law, 2 (2017).

7. A.S. Kasatkina, International marine transportation of cargo: topical problems of legal regulation, Law. HSE Academic Journals, 2 (2016)

8. T.V. Glinshchikova, Development of international legal regulation of the sea carrier liability, Problems of economics and legal practice, 17(3) (2021).

9. Iu.S. Usacheva, Limits of liability of a sea carrier, Economy. Law. Society, 4(16) (2018).

10. Kh.M. Musaeva, Sea freight transportation. Responsibility of the cargo carrier, Baltic Humanitarian Journal, 3(32) (2020). 